\title{
"Prisoner Never Gave Me Anything for What He Done:" Aboriginal Voices in the Criminal Court
}

Shelley A. M. Gavigan

Osgoode Hall Law School of York University, sgavigan@osgoode.yorku.ca

Source Publication:

Socio-Legal Review. Volume 3 (2007), p. 71-99.

Follow this and additional works at: https://digitalcommons.osgoode.yorku.ca/scholarly_works c) (1) $(9)$

This work is licensed under a Creative Commons Attribution-Noncommercial-No Derivative Works 4.0 License.

\section{Recommended Citation}

Gavigan, Shelley A. M. "'Prisoner Never Gave Me Anything for What He Done:" Aboriginal Voices in the Criminal Court." Socio-Legal Review 3 (2007): 71-99.

This Article is brought to you for free and open access by the Faculty Scholarship at Osgoode Digital Commons. It has been accepted for inclusion in Articles \& Book Chapters by an authorized administrator of Osgoode Digital Commons. 


\section{"Prisoner Never Gave Me Anything for What He Done:" Aboriginal Voices in the Criminal Court ${ }^{*}$}

\section{Shelley A.M. Gavigan ${ }^{* *}$}

Aboriginal people participated in different ways in the criminal process in the early years of the North-West Territories region of Canada: including, as accused persons, as Informants, and as witnesses. Their physical participation was often mediated by the police, Indian agents and sometimes their Chiefs. Their words were also mediated by interpreters, both linguistic and cultural, and their signatures invariably marked as " $X$ " on their depositions. Scholarship that has examined the relationship of Aboriginal peoples to the criminal law has tended to interrogate the criminalization and moral regulation strategies implicit in the process of colonization and domination of the First Peoples. This paper will discuss less visible aspects of the legalized processes of colonization: (1) the participation of Plains Cree, Saulteaux and Métis peoples, among others, whose traditional values and norms nonetheless seep through the handwritten, translated transcription and alien norms of the Canadian criminal court; and, (2) cases in which Aboriginal complainants who, notwithstanding their substantive inequality, invoked the criminal process to insist that those who wronged them also be punished in accordance with the principles of Canadian law.

In colonial law, $\ldots$ it is tempting but wrong to view any participation in an imposed legal system as collaboration, on the one hand, and to represent any form of rejection of the law's authority as resistance. ${ }^{1}$

\section{Introduction}

Criminal law is generally understood to be the perfect expression of a coercive legal form, expressing as it does the power of the state to criminalize, to enforce, and to punish. This article, concerned with a particular form of

\footnotetext{
${ }^{*}$ Earlier versions of this article were presented at the Legal History Workshop, Faculty of Law, University of Toronto, Toronto, Ontario, Canada (March 2003), at the Annual Meeting of the Canadian Law \& Society Association (University of Manitoba, 2004), and at the Department of Sociology and Anthropology, Simon Fraser University, Burnaby, British Columbia, Canada, February 12, 2007.

** Professor, Osgoode Hall Law School, York University, Toronto.

${ }^{1}$ Benton, Law and Colonial Cultures: Legal Regimes in World History, 1400-1900 17 (2002).
} 
criminal law in a particular social and historical context, argues that even this coercive legal form is replete with contradictions that challenge this ascribed quintessence. That criminal law in nineteenth century Western Canada enforced and reinforced relations of inequality is undeniable. However, that the criminal law also mediated these relations and, on occasion, inhibited the powerful and afforded some protection to those with less power - even in the context of colonial domination and gross substantive inequality - is a central argument. $^{2}$

This article forms part of a larger study that attempts an in-depth analysis of the relationship between the First Nations and the criminal law in the 'Saskatchewan' region of the North-West Territories (NWT) of Canada in the last quarter of the nineteenth century. No period witnessed more profound social transformation in and for the lives of the First Peoples of that region. My research analyzes the role of Canadian criminal law in this watershed period.

\section{The Canadian State and the First Peoples of the Plains after 1870}

This land provided us with many things, gave us a good life and we were able to survive by all the resources available to us. ...If the whiteman had a better understanding of what the land meant to us he would have thought differently about us. ${ }^{3}$

It is difficult to say with certainty what the population of the indigenous peoples was when in 1870 the vast regions of Rupert's Land (previously held by the Hudson's Bay Company by virtue of the Royal Charter of 1670) and the Indian Territory were incorporated into Canada as the North-West Territories. The region was home to the Plains, Swampy and Woodland Cree, the

${ }^{2}$ I acknowledge an explicit debt to E.P. Thompson:

If we suppose that law is no more than a mystifying and pompous way in which class power is registered and executed, then we need not waste our labour in studying its history and forms. One Act would be much the same as another, and all, from the standpoint of the ruled, would be Black. It is because law matters that we have bothered with this story at all. ...It is only when we follow through the intricacies of its operation that we can shossw what it was worth, how it was bent, how its proclaimed values were falsified.

Thompson, Whigs and Hunters: The Origin of the Black Act 267-268 (1977).

${ }^{3}$ The late Senator John Tootoosis, speaking at the Treaty Six Centennial Commemoration in 1976: Sluman and Goodwill, John Tootoosis: A Biography of a Cree Leader 1 (1982). Senator Tootoosis was the grandson of Yellow Mud Blanket, the brother of Chief Poundmaker. 
Assiniboine (Nakoda, Stone Sioux, or Stonies), and the Saulteaux (Plains Ojibway) peoples. ${ }^{4}$ Further to the west lived the Blackfoot Confederacy (the Blood, Siksika and Peigan) and Tsuu T'ina (Sarsi) peoples. ${ }^{5}$ People of mixed Indigenous and European ancestry with strong associations, including familial, to both the HBC and the First Nations also called the territories home. In the official records and documents of the period, these many peoples invariably were referred to respectively as "Indians" and "Half-Breeds", now First Nations and Métis. Although maps of the region tend to situate the Cree, Saulteaux, and Assiniboine in discrete geographic territory, Aboriginal scholars of the region and period emphasize that the inter-relatedness of the Nations. ${ }^{6}$ Cree appears to have been the lingua franca ${ }^{7}$ - but the lines between the Nations may have been fluid as suggested by no less than the lineage of some of the leading Plains Cree leaders of the period: ${ }^{8}$

Precise numbers are elusive. The total population of the Plains in 1870 was probably between forty and fifty thousand persons. ${ }^{9}$ The region was then

${ }^{4}$ See, e.g., the map reproduced in Pettipas, Severing the Ties That Bind: Government Repression of Indigenous Religious Ceremonies on the Prairies xiv (1998). See also, Milloy, The Plains Cree: Trade, Diplomacy and War, 1790 to 1870 Map 1 (1990).

${ }^{5}$ Pettipas, $i d$.

${ }^{6}$ McLeod, Plains Cree Identity: Borderlands, Ambiguous Genealogies and Narrative Irony, 20 Can. J. Native Stud. 455-486 (2000).

${ }^{7}$ McLeod, id.

${ }^{8}$ Chief Poundmaker was the orphaned son of an Assiniboine father and Cree, or Métis, mother, nephew of the Cree Chief Mistawasis, and adopted as an adult by the Blackfoot Chief, Crowfoot. Piapot was Cree but had been raised by his grandmother in a Sioux camp after they had been captured during a raid; Sweet Grass, one of the principal Chiefs of the Crees and spokesperson at the Fort Pitt signing of Treaty Six, is said to be been a fullblooded Crow. Big Bear was the son of Black Powder, a prominent Ojibway leader who had moved from further east (now Ontario). The name and nation of Big Bear's mother is apparently not known, but she may have been Cree, as her son, and his father before him, led a mixed band of Cree and Saulteaux: see Dempsey, Big Bear: The End of Freedom 29 (1984); McLeod, supra note 6; Sluman, Poundmaker (1967); Miller, Big Bear [Mistahimusqua]: A Biography (1996).

${ }^{9}$ Figures provided in the Report of the Special Committee of the House of Commons, 1857, of "Establishments of the Hudson's Bay Company in 1856, and Number of Indians frequenting them" indicated that 22,050 Indians attended at the Hudson's Bay posts that figure prominently in Hugh Richardson's court records. Report of the Special Committee of the House of Commons, 1857 C. Appendix No. 2, pages 365,366 and 367), in Statistics Canada, Censuses of Canada 1865-1871, The Aboriginal Peoples at 12-13, available at http://www.statcan.ca/english/freepub/98-187-XIE/aborig.htm. The figures suggest a more significant presence in the northern districts: the more northern posts, Edmonton (7500), Carlton (6000), Fort Pitt (7000), Lac La Biche (500) far exceed those for the more southern posts (Fort Ellice (250), Qu'Appelle Lakes (250), Touchwood Hills (300) and Egg Lake (200). The Census of 1871 reported that the population of the "Plains Tribes (Blackfeet, etc) totalled 25,000. For the year 1871, the total Aboriginal population for Labrador, Rupert's 
home to the First Nations, who numbered between 25,000 and 35,000. However, over the next twenty years the new NWT experienced an unprecedented and irrevocable transformation in its population. By 1880-1881, there were eleven settlements in the NWT, the total population of which was 33, 172, with the First Nations accounting for all but $6,000 .{ }^{10}$ Over the next ten year period, the "Indian" population dropped dramatically: by 1891, the population of the Territories was 66,799 , of which only 15,000 or so would have been Indians. ${ }^{11}$

Thus, in the twenty years following the incorporation of the NWT into Canada, the population of the Plains First Nations was reduced by half. The ravages of disease, such as small pox, alone cannot account for this tragic attrition; one has to consider the demise of the buffalo, the loss of the commons, ${ }^{12}$ the relegation to reserves, restrictions on movement, and the determination of the Canadian government not to ameliorate, but rather to pursue policies that ensured, starvation and immiseration, designed to enforce the transition from traditional way of living to the new. In the midst of this well-documented catastrophe, I argue that the criminal law, while neither neutral nor benign, played a modest and often mediating role.

Land and North West was estimated to be 55,500, while "other races" were estimated to number 5,000. Statistics Canada, Censuses of Canada 1865-1871, The Aboriginal Peoples, available at http://www.statcan.ca/english/freepub/98-187-XIE/aborig.htm (last visited Jan. 20, 2004).

Historian Olive Dickason puts the population figures for the Aboriginal population in 1870 about 35,000 with Métis about 10,000-12,000; and whites, fewer than 2,000: DicKASON, Canada's First Nations: A History of Founding Peoples from Earliest Times 97 (1992). See also, Spry, The Tragedy of the Loss of the Commons in Western Canada in As Long AS THE Sun Shines and Water Flows: A Reader in Canadian Native Studies 203 (Getty and Lussier, eds., 1983).

10 Williams, Law and Institutions in the North-West Territories (1869-1905), 29 SASKatchewAN Bar Review 51, 56 (1964). Relying on Census of Canada, 1880-81, records, Williams lists the following locales where Métis or white settlers were reported: Cumberland (population: 1,255, of which 1,125 were Indians), Qu'Appelle (population: 5,241, of which 4,593 were Indians), Wood Mountain (population: 4,552, of which 4,143 were Indians), Prince Albert (population: 3,236, of which 1,075 were Indians), Battleford (population 4,830, of which 3,978 were Indians), Edmonton (population: 3,056, of which 2,326 were Indians), Bow River (population: 2,875, of which 2,326 were Indians) Oxford House (population: 535, of which 503 were Indians), Norway House (population: 528, of which 500 were Indians), Peace River (population: 2,315, of which 2,038 were Indians), Eastern Rupert's Land (population: 4,349, of which 4,016 were Indians). The total population of these 'settlements' in the Territories was 33, 172, of which 27, 172 were Indians. The entire population of the Territories was given as 56,446 , as it was estimated that there were a further 23,274 Indians "scattered" over the plains.

${ }^{11}$ Census of Canada 1890-1891 (Ottawa: Queen's Printer, 1893), Volume I, Table II at 112.

${ }^{12}$ See Spry, supra note 9. 
My research is based upon two sets of criminal court records of Stipendiary Magistrate Hugh Richardson: ${ }^{13}$ the first set dates from 1876 to 1886 (comprising most of "The Richardson Papers" held by the Saskatchewan Archives Board in Regina, Saskatchewan, Canada $)^{14}$ and the second set, his court files from his time on the bench of the Supreme Court of the North West Territories, from 1887 until his retirement in $1903 .{ }^{15}$

The collection covering the early period (1876-1886) contains two hundred eighty-two (282) records, thirty-nine (39) of which relate to non-criminal matters (breach of contract (including breach of contract of employment, nonpayment of wages, debt, wrongful dismissal). Of the remaining two hundred forty-three (243) criminal court matters, one hundred ten (110) cases (45.26\%)

${ }^{13}$ Hugh Richardson dispensed criminal and civil justice in the North-West Territories (NWT) for the last twenty-three years of the nineteenth century. His tenure on the bench coincides with a period of monumental social, economic, political and legal transformation of the region, of which his courts were a part.

$\mathrm{He}$ is not a household name, even for Canadian legal historians. A flicker of acknowledgement tends to occur when his name is mentioned in relation to Louis Riel, the most famous accused person to appear in his courtroom. The 1885 treason-felony trials of Cree leaders, Pîhtokahanâpiwiyin (Poundmaker) and Mistihai'Muskwa (Big Bear) over which he also presided have been described by legal historian Sidney Harring as the most famous Indian criminal trials in Canadian history, and even they, more aptly understood as political trials, are not particularly well known. His formal contribution to Canadian legal history appears to be simply a controversial flash in the pan. He sentenced Riel to hang and this for many is his claim to infamy.

And yet, he was the first magistrate before whom the First Nations peoples of the Saskatchewan region would appear who was not also an officer of the Hudson's Bay Company (HBC) or the North-West Mounted Police (NWMP). He issued the first cautions and deferred sentences, and imposed the first terms of imprisonment that the First Nations experienced. His was the first trial court to dispense a new form of justice based on new concepts of wrong, bringing new forms of punishment to the Cree, Nakoda (Assiniboine) and Saulteaux peoples. He issued the first cautions and deferred sentences, and imposed the first terms of imprisonment that the First Nations experienced. He retired in 1903, before his region of the NWT was reconfigured in 1905 as the province of Saskatchewan, and his Court succeeded in 1906 by the Supreme Court of Saskatchewan. See Sidney L. Harring, "There Seemed to Be No Recognized Law": Canadian Law and the Prairie First Nations, Laws AND Societies in the Canadian Prairie West 1670 -1940 92, 98 (Louis A. Knafla and Jonathan Swainger eds., 2005); Thomas Flanagan, Hugh Richardson, 14 Dictionary of Canadian BIOGRAPHY 872-873 (1910-1913).

${ }^{14}$ This collection is located at the Saskatchewan Archives Board (Regina) in the Records of the Department of the Attorney-General, Regina Judicial Centre: Court Records, First Series, Files $1-282,1876-1886$. There is no collection number for these records, which currently can be found on shelf location $\mathrm{H}-1198.5 .4$ in the Regina office of SAB. In this dissertation, I identify the files from this set of records as follows: SAB A-G (GR 11-1) CR-Regina, $1^{\text {st }}$ series, 1876 - 1886, file \#.

${ }^{15}$ This collection is located at the Saskatchewan Archives Board (Regina) (SAB) in CRRegina RG 1286. 
seem to involve Aboriginal persons ${ }^{16}$ as Accused persons where individuals identified specifically as "Indian" accused are found in seventy-one (71) files (or 29.2\%) . Some of these cases, notably the cases in which theft of horses was alleged, involve more than one accused person. ${ }^{17}$ In fifty-four (54) cases (22\%), the Informant or Complainant appears to have been an Aboriginal person (those described only as "Indian" are found in twenty (20, or $8.2 \%$ of the files).

A few general observations can be made here. In the early period, where most of the population of the NWT was First Nations (e.g., Cree, Saulteaux, Assiniboine), they nonetheless appear as accused persons in significantly fewer numbers. Most accused persons were held in custody in the gaol of the police barracks and thus appeared in court as prisoners. Most criminal prosecutions (as opposed to liquor violation prosecutions) were commenced by Informants who were private individuals, not police officers swearing on information and belief. Most Informants knew by name the individual they alleged had committed the offence. It appears that most Informants and accused persons

\footnotetext{
${ }^{16}$ I am mindful that these figures are somewhat imprecise. Some of the Accused persons are described in the documents as "a Cree Indian," "a Sioux Indian," and so on (e.g. Ochaque, a Saulteaux Indian, otherwise "the Fisher" (1879/80), SAB A-G (GR 11-1) CR-Regina, $1^{\text {st }}$ series, 1876 - 1886, file \# 96). Some of the names are clearly those of an Aboriginal person (e.g., Ka-Ki-Si-Kut-Chin, also known the Swift Runner (1879), SAB A-G (GR 11-1) CRRegina, $1^{\text {st }}$ series, $1876-1886$, file \#65); whereas others are revealed by the context and contents of the file to be an Aboriginal person (e.g. Joseph Cardinal (1880), SAB A-G (GR 11-1) CR-Regina, $1^{\text {st }}$ series, 1876 - 1886, file \#104). In some instances, I have drawn an inference by virtue of the fact that the Francophone name names (e.g. Plante, Ballendine, Poitras, Trottier, Delorme, Pruden, Cardinal, Venne, Letendre, Lavallée, to cite but a few) and/or community (e.g. St. Laurent, Lac La Biche, Duck Lake,) are generally known to be prairie Métis. See: Department of Interior, Dominion Lands Branch - Application for Scrip 1886-1901, 1906 made by North-West Half Breeds. SAB R 91-7 Coll. R-5.11 File No. C14943. See also Payment's discussion of the Métis families of early Batoche. Payment, Batoche After 1885, A Society in Transition, in 1885 and After: Native Society in Transition 173, 175-78 (Barron and Waldram, eds., 1986). In other cases, an individual was described in the file as a "Half-breed" or "Half-breed Indian" (e.g. Scholastique Cardinal (1882), SAB AG (GR 11-1) CR-Regina, $1^{\text {st }}$ series, 1876-1886, file \#145). For the purposes of this calculation, I have included Cree, Saulteaux, Assiniboine (Stoney), Sioux, Blackfoot and Half-breed within the meaning of "Aboriginal." I have also included every file where an interpreter for an Aboriginal language is indicated in the file. It should be noted that only the term "half-breed", never the word "Métis, appears in the documents, having acquired a form of legal legitimacy by its inclusion as a legal term in the 1876 Indian Act: see Sanders, The Queen's Promises, in Law and Justice in a New Land: Essays in Western Canadian Legal History 101, 109 (Barron and Waldram eds., 1986).

${ }^{17}$ See, e.g., Chac-a-Chas and six others, (1884) SAB A-G (GR 11-1) CR-Regina, $1^{\text {st }}$ series, 1876 - 1886, file \#143; The Rock, Little Fish, and Is-te-wah, three Cree Indians (1884), SAB A-G (GR 11-1) CR-Regina, $1^{\text {st }}$ series, 1876 - 1886, file \#226.
} 
had a social or legal relationship prior to and/or giving rise to the matter before the court.

Most property related offences involved forms of larceny of 'subsistence goods' (flour, sugar, bacon, tea, matches, trousers, socks, vests, as well as livestock and horses) but some involved theft of ribbon, watches, buttons, and other readily carried and concealed objects. The major victims of property offences were the government and the Hudson's Bay Company (HBC).

\section{Aboriginal Voices in the Criminal Court}

The insights of legal pluralism are deployed by some scholars to provide a different way of understanding the relational nature of the legal encounters between the Anglo-European-Canadian authorities and the First Nations. This approach also invites researchers to look for ways in which Aboriginal norms and processes influenced as well as were influenced by the dominant legal system.

In an article which addresses the provenance and nature of Aboriginal Rights, Jeremy Webber makes a brief excursion into criminal law, specifically murder, to make a case for the development and operation of intercommunal norms. ${ }^{18}$ Webber argues that the internal norms of the Aboriginal and nonAboriginal societies influences a new emergent normativity "but not in the straight-forward, deductive fashion often supposed:"

The distinctive norms of each society furnished the point of departure, determining the spirit of interaction, colouring the first interpretations of the other's customs, and shaping the beginning of a common normative language. But the final result was above all the result of mutual adaptation, in which the structure of the relationship was formed as much from compromises on the ground as from abstract principles of justice. ${ }^{19}$ (Emphasis added)

Webber does not claim that a "new cross-cultural community" was created which displaced its "constituent societies:" "Its aspirations were modest,

\footnotetext{
${ }^{18}$ Webber, Relations of Force and Relations of Justice: the Emergence of Normative Community between Colonists and Aboriginal Peoples, 33 Osgoode Hall L. J. 623-670 (1995).

${ }^{19} I d$. at 626-627.
} 
restricted to intercommunal relations." ${ }^{20}$ Nor does he deny the dynamics of power, the role of force, and the substantive inequality between Aboriginal peoples and non-Aboriginal peoples. However, he holds onto the possibility of "a negotiated normative order in situations of domination."21

Lauren Benton also engages with the issue of engagement and participation of aboriginal peoples in colonial legal system:

... In the colonial world, indigenous legal actors are not necessarily collaborators if they take actions that affirm the legitimacy of colonial courts. The knowledge of the harm inflicted by legal institutions coexists with the knowledge that they are a part of a larger spectrum of behaviours and beliefs that constitute law. It is possible simultaneously to use imposed authority (thereby reaffirming it) and to seek to undermine its authority. ${ }^{22}$

Benton and Webber offer support for a more relational analysis of colonial laws, including criminal laws, in which the relevance of agency, struggles and compromises forged 'on the ground' may be found even in communities comprised of heterogeneity, diversity and substantively unequal relationships. I do not argue that Benton and Webber's approach offers a new, improved 'one model fits all' framework for the study of colonial legal regimes, rendering other work on other periods and locations less probative. Indeed, one finds in their work an insistence on the existence and relevance of agency of subordinated peoples that one also finds in Tina Loo's work on nineteenthcentury British Columbia. ${ }^{23}$

The focus in this article represents a shift from a traditional if understandable preoccupation of socio-legal historians of criminal law with the criminal prosecutions of Accused persons upon whom the coercive form of the law is expressed, and by whose numbers it is counted and its efficacy is measured. The criminal process involved many more ordinary people as well, some of whom invoked the criminal law for support, protection and redress.

\footnotetext{
${ }^{20} I d$. at 627.

${ }^{21} \mathrm{Id}$. at 629.

${ }^{22}$ Benton, supra note 1, at 258.

${ }^{23}$ See, e.g., Loo, Dan Cranmer's Potlatch: Law as Coercion, Symbol, and Rhetoric in British Columbia 73 Can. Hist. Rev. 125-165 (1992); Loo, Tonto's Due: Law, Culture, and Colonization in British Columbia, in Making Western Canada: Essays on European Colonization and Settlement 62 (Cavanaugh and Mouat, eds., 1996) [hereinafter Loo (1996)].
} 
To analyze the enforcement of criminal law only through the usual suspects the police, the prosecutor and the accused - is to identify only the most visible aspect of the criminal process, and to miss the more contradictory nature of this legal form, in which social relations of inequality are not simply enforced, but also mediated.

In this article, I turn to Aboriginal voices in the court through cases in which Aboriginal persons in the Plains region of the nineteenth-century NWT turned to criminal law and invoked its processes, including a number of cases of First Nations Chiefs and other leaders as Informants, Aboriginal women complaining of domestic and sexual violence at the hands of both white and Aboriginal men, and others who insisted that the law "ought to protect them," and through cases in which Aboriginal persons appeared as witnesses invariably through interpreters. This focus allows one to engage with and consider the implications of the analyses and arguments advanced above by Benton and Webber. What then can be said of the nature of the contribution of the criminal law, and the relatively small numbers of people who came before the criminal courts either as prisoners, informants or witnesses?

\section{i. Aboriginal Informants}

In a document neither sworn nor dated, a man name Is-pinik-hah-kee-toot complained that in the winter of 1874-1875, his brother-in- law Apistatim had taken seven horses, without authority, from Is-pinik-hah-kee-toot's father (since dead). ${ }^{25}$ With the assistance of the police at Tail Creek, Is-pinik-hah-keetoot, described throughout the document as "Complt" had recovered six of the horses, but his brother-in-law had come the previous summer and made off with six horses that he owned. Friends of Is-pinik-hah-kee-toot had retrieved these horses, but in October 1877, Apistatim had returned in the complainant's absence and taken three horses which he never returned. Apistatim is described in the complaint as being non-treaty and in Big Bear's camp. ${ }^{26}$ Is-

\footnotetext{
${ }^{24}$ Mr. \& Mrs. Bokas in Chaton's case (1902).

${ }^{25}$ Apistatim (1878), SAB A-G (GR 11-1) CR-Regina, $1^{\text {st }}$ series, 1876 - 1886, file \# 42.

${ }^{26}$ Big Bear was one of the leading Cree Chiefs of the region in this period. He was among the longest holdouts to enter into a Treaty with the Canadian government; suspicious of the government's real intentions, he likened the government's invitation to enter into a treaty as "bait to a trap:" Dempsey, supra note 8 . He and his people ultimately were really starved into submission, and in 1885 his conviction and imprisonment following the 1885 Rebellion represented a monumental defeat for Big Bear and his people. His band was dispersed and he died within months of his release from prison in 1887. In 1876, the fact that the alleged accused in this case was "non-treaty" meant that his Chief and Headmen had not agreed, by
} 
pinik-hah-kee-toot estimated that the three horses were worth $\$ 75.00$ each. His witnesses are said to be "the whole camp" and he concludes that he himself will be back at his camp in about seventeen days. The court file is one single sheet of paper, and not surprisingly there is no disposition, much less a hearing, into the complaint.

The fact that the matter was not resolved is of less interest to me than the fact of the complaint itself. Clearly this was a dispute between extended family members; it seems that Is-pinik-hah-kee-toot was acting in the capacity akin to an executor in his efforts to reclaim his father's horses from his brother-in-law. The dispute over the horses is not one which less than a decade earlier would have witnessed the involvement of police or the white man's court, and yet a clearly exasperated Is-pinik-hah-kee-toot turned to the law for assistance, not once but twice. Perhaps he was a Treaty Indian who felt he had a right to assistance from the Canadian authorities in dealing with his non-treaty brotherin-law who kept stealing his horses.

While not overwhelming in numbers, it is clear from Richardson's court records that First Nations individuals invoked the assistance of the criminal law. Many of the cases I have read involved First Nations complainants and informants: Peaychew (he and his Chief enlisted the assistance of the police when Peachew's young daughter went missing on a hunting trip), William Wolf (a Cree man who complained that three Assiniboine men from a neighbouring reserve stole his horses), Na-tox-kris-tok-ka (or The Only Mountain, a Blackfoot man who complained to the police that a young Cree man had stolen his horse), Margaret Gladieu (who laid a Complaint that her Cree son-in-law murdered her husband), Alexis Sussey (a young Assiniboine who complained that two other Assiniboine men had murdered his parents and siblings), and so on. In addition to these files, the court records indicate that a number of Aboriginal women charged their husbands with forms of assault. ${ }^{27}$ The participation of First Nations leaders, notably of Chiefs and their

virtue of the Treaty, to assist the police in bringing a wrongdoer to justice.

${ }^{27}$ For example, at Fort Pitt, a Cree woman named Margaret charged her husband I-ah-peekoo-caw with threatening bodily harm: (1881), SAB A-G (GR 11-1) CR-Regina, $1^{\text {st }}$ series, 1876 - 1886, file \#115 Kah-kiche-Inew charged her husband Jean Marie with assaulting her with a knife, although this charge was withdrawn at her request: Jean Marie (1881), SAB AG (GR 11-1) CR-Regina, ${ }^{\text {st }}$ series, 1876 - 1886, file 118. The Little Girl, a Saulteaux Indian charged her husband with assault after he split her head open with an axe: Hoh-pie-sah-pah, otherwise Blacknest (1882), SAB A-G (GR 11-1) CR-Regina, $1^{\text {st }}$ series, 1876 - 1886, file \# 155. The 22 July 1882 issue of the Saskatchewan Herald reported that owing to the great (but nowhere described) provocation, Blacknest's sentence was a modest ten days at hard labour in the Battleford police station. 
Councillors, figure significantly among the thirty "Indian" Informants in the early period. The Richardson files suggest that even when not named formally as Informant, Treaty Six Chiefs (e.g. Red Pheasant, Beardy and Strike Him in on the Back) were prepared to use the police and the court for assistance. ${ }^{28}$

In my view, one of the most interesting if least resolved case of an Indian leader as Informant is that of Oo-pee-too-kah-ran-up-see-we-yin, referred to in the court file as "the Pondmaker."29 I believe that The Pondmaker is undoubtedly the man known now to us as Poundmaker (Pitikwahanapiwiyin), head man of the River People, and spokesperson at Treaty Six negotiations, and one of the prominent Chiefs convicted and sentenced in 1885 to three years in prison for felony treason. ${ }^{30}$

In August 1878, The Pondmaker swore an Information, as a Christian Indian, before Hugh Richardson, interpreted by Peter Erasmus, ${ }^{31}$ that John Ballendine had stolen his horse. The horse had been the subject of a wager

See also, Macleod and Rollason, Restrain the Lawless Savages: Native Defendants in the Criminal Courts of the North-West Territories, 1878 - 1885, 10 J. Hist. Sociology 157183 (1997) at 176-77 discuss the use of the criminal law made by the Blackfoot Chief, Stamistocotar (Bull Head) in his prosecution of Joseph Gouin. Stamistocotar consciously invoked the 'Queen's law' when he charged Gouin with theft of a horse, arising out an incident which reflected either a misunderstanding or a breakdown in their relationship and the meaning of gifts that had been exchanged between them. Gouin was convicted by Richardson and sentenced to three months hard labour. This case is in the first series of Richardson's records, Joseph Gouin (1879), SAB A-G (GR 11-1) CR-Regina, $1^{\text {st }}$ series, 1876 - 1886, file \#72.

${ }^{29}$ John Ballendine (1878), SAB A-G (GR 11-1) CR-Regina, ${ }^{\text {st }}$ series, $1876-1886$, file \# 29.

${ }^{30}$ The Treaty Commissioner, Alexander Morris, named him as Oo-pee-too-kerah-han-ap-eewee-yin (the Pondmaker): The Treaties of Canada with the Indians of Manitoba and the North West Territories (2000), at 210; at 219, he appears as 'Oo-pee-too-korah-hair-ap-eewee-yin' (the Pond-maker). The many spellings of his name in translation illustrate the difficulty one has in asserting with confidence the identity of the persons named in the court files. Poundmaker himself arguably illustrates, as well, the fluidity of relations among the First Peoples of the Prairies, and why it is a trap for the unwary to insist upon rigid distinctions between "Indian" and "Métis", Cree and Saulteaux, and even that the description of him as a "Cree" may not be how he would have described himself: He was the son of Sikakwayan, a Stoney shaman, and a Métis mother. On his mother's side, he was a nephew of the prominent Chief, Mistawasis, and he was as well the adopted son of the Chief of the Blackfoot, Crowfoot. His brother, Yellow Mud Blanket (or as he was named in the court file, Yellow Earth Blanket) like Poundmaker, was also prosecuted after the 1885 Resistance/Rebellion. Unlike Poundmaker, who was sentenced to three years in the Penitentiary Yellow Mud Blanket was released by the Court on the recommendation of Crown Counsel; see Bingaman, The North-West Rebellion Trials, 1885 Appendix A, at 206 (1971) (Master's Thesis, University of Regina); see also Bingaman, The Trials of Poundmaker and Big Bear, 188528 Saskatchewan History 81-94 (1975); Stonechild and Waiser, Loyal Till Death: Indians and the North-West Rebellion (1997); Beal and Macleod, Prairie Fire: The 1885 North-West Rebellion (1984). 
between Ballendine and the Pondmaker on a horse race that they had agreed would be run over the course of a mile; they had shaken hands on the wager. Ballendine had told the Pondmaker that twenty-seven telegraph poles measured one mile, and although one in the Pondmaker's party (Pierre Daignault) disputed this, saying 31 poles comprised one mile. The Pondmaker accepted Ballendine's word when he insisted it was 27 poles to the mile. The race was run, Ballendine's horse won. After the race, a man named Todd told Pondmaker that "he heard I had lost the race and that there was some foul play about it." With the assistance of the surveyor's camp crew, a measure was taken, and indeed a further 7 poles beyond the 27 th made up the distance of one mile. Pondmaker went to Ballendine and told him where the horse was and that he was satisfied that a mile had not been run, and proposed yet another race. Ballendine declined to race his horse again. Faced with Ballendine's intransigence, the Poundmaker "consulted Mr. Brelland who told me to go to Mr. Richardson and lay a complaint. I was afraid to do so as I had heard from Daignault and others I might be punished for gambling. Mr. Brelland insisted I should go and I went." Pondmaker continued:

After seeing Mr. Richardson I went with Lazare to Ballendine and Lazare told him as I understood what $\mathrm{Mr}$. $\mathrm{R}$ had directed. Ballendine made rough reply in English. Ballendine afterwards in my absence went to my camp and took my horse.

In this matter, Pondmaker had been assisted by the Survey crew and by Peter Erasmus; he invoked the highest levels of authority in Battleford, consulting with "Mr. Brelland," likely Paschal Breland, Métis member of the North-West Council, who sent him to Richardson (who was also a member of the Territorial Council). ${ }^{32}$ Richardson clearly had sent a message to Ballendine through Lazare, and the Pondmaker's English was sufficiently good to understand a "rough reply." No new race was run, and Ballendine surreptitiously made off with his horse. The Poundmaker's Information was laid, not before a justice of the Peace, but before the more senior Stipendiary Magistrate, Richardson himself. Whether or not he experienced being cheated as a humiliation, the Pondmaker's indignation at the "foul play" is matched by the unresolved nature of the matter in the court file.

\footnotetext{
${ }^{31}$ Peter Erasmus had acted as interpreter for the Indians during the Treaty Six negotiations: see Morris, The Treaties of Canada at 196.

${ }^{32}$ Thomas, The Struggle for Responsible Government in the North-West Territories (1978).
} 
Even when not named in the Information as "Chief", some of the charges clearly were laid in that capacity, on behalf of their Band members (or the Band's resources). For instance, on Chief Beardy's Information, Francis Deschaw was charged and convicted in 1878 for theft of clothing and money, the property of Beardy's band. ${ }^{33}$ Deschaw had accompanied Beardy and his Councillors to Winnipeg shortly after their Treaty money had been paid. Deschaw had helped himself to a pair of trousers and a coat from the goods that they purchased, wore them on the trip back, never paid for them, and upon conviction for theft, was sentenced to six months hard labour at the Battleford police station.

On October 6, 1882 a Cree man named Ka-nah-pic-a-nah-haw, also known as the Snake Indian, was accused in an Information sworn on information and belief by Metchewais, a Councillor of Strike Him on the Back's band:

...that Ka-nah-pic-a-nah-haw or the Snake Indian a Cree Indian of band on the fourth day of October inst. at Strike him on the Back's Reserve by force and against her will, feloniously ravished and carnally knew K, an Indian girl, a daughter of [KOAP] a Cree Indian under the age of twelve years. I was told this by some who knew of it. ${ }^{34}$

At the trial of the Snake Indian, the girl described through the interpreter what the prisoner had done to her, and what she had done afterwards. ${ }^{35}$ The second witness was her mother:

I live at the Battle River Indian Reserve. Know the prisoner who is my present husband. The last witness is my daughter by a previous husband. She is past seven years of age. Recollect when Indians at the Reserve were lately paid, and prisoner sending the girl off for potatoes. Prisoner followed shortly after. Late on the same day I was told by an Indian woman called KNDT that prisoner had [violated?] the girl. I then examined the girl and found her privates injured and blood flowing. Prisoner at this time was away.

\footnotetext{
${ }^{33}$ Francis Deschaw (1878), SAB A-G (GR 11-1) CR-Regina, $1^{\text {st }}$ series, 1876 - 1886, file \# 57.

${ }^{34}$ Ka-nah-pic-a-nah-haw or the Snake Indian. (1882), SAB, A-G (GR 11-1) CR-Regina, $1^{\text {st }}$ series, 1876 - 1886, file \# 172. It is not clear from the file who KAOP is; given that the mother's name is somewhat different (see below), it may be that KAOP is the name of K's father. The names of these witnesses appear in the court file, and I have a record of them. I have elected not to use the child's name, or that of her mother or grandmother.

${ }^{35}$ In Richardson's notes a last line of her evidence is crossed out: "When I got home soon after I told my mother."
} 
She then appeared to direct herself to the prisoner, perhaps in response to a question by him:

To Prisoner: I examined the child carefully. Prisoner never gave me anything for what he did. I never consented that prisoner should sleep with the girl, nor did he ever ask me to do so.

The third and final witness, KNDT, testified that the girl was her grandchild and that she had found standing in water and crying: "I asked her what was the matter. She replied that prisoner had connection with her in the bush pointing to a bush near by...I then told the girl's mother."

Someone, it is not clear who, must have contacted Councillor Metchewais, and perhaps even Chief Strike Him on the Back. The matter was brought to court, and it seems that the child's mother was herself kept in custody until the trial. ${ }^{36}$ While Richardson's file does not indicate the disposition in the case, the Annual Report of the NWMP indicates that a prisoner named Ka-na-pic-a-nahon (Snake Indian) was convicted by Judge Richardson and sentenced to five years at Manitoba Penitentiary.

It may be that the Snake Indian was not a member of Strike Him on the Back's band, given that his Band was left blank on the Information, which may also explain why Metchawais and KNDT each pursued the matter, and it may be also that the child's mother was a reluctant witness which is why she was likely also held in custody. And, while the Prisoner appeared to have asked no questions of the child and the grandmother, he seems to have asked a question of his wife, which gave rise to her answer that she examined the child and she never consented to him sleeping with the child.

It is possible that the Snake Indian had not apologized to his wife and offered no compensation for the assault upon her child and the consequent injury to her. Or perhaps, his question to her addressed this; perhaps he had attempted a form of reparation and she had not accepted it or simply denied that it had been offered. And, clearly she denied that she had consented to his conduct.

Other Aboriginal peoples laid Informations before a justice of the peace or the stipendiary magistrate, including women complaining of mistreatment by

\footnotetext{
${ }^{36}$ The entry in the Report of the Commisioner of the North West Mounted Police indicates that a witness named Ka-nha-neh-can-mokin was released on the same day as Ka-na-pic-a-nahon (Snake Indian) was convicted: Report of the Commissioner of the North West Mounted Police, 1882, Appendix D at 41.
} 
men who were not their husbands. Sometimes, the accused was a husband or man with whom she had wintered; in other files, the accused is a prominent merchant (e.g. prominent Battleford merchant, J.B Mahoney ${ }^{37}$ ) accused of indecent assault, or a member of the NWMP accused of theft following "connection" for money. A Battleford man, William Williams, was convicted in 1882 of assaulting a woman described as "A certain Cree Indian woman know as Little Duck" and required to pay a fine of $\$ 5.00$ and $\$ 4.50$ to Little Duck. $^{38}$ In NWMP Cst. James Ford's case, the Informant, O-cha-nah-kis, told of his coming to her camp, "calling for a woman" and had paid her $\$ 1.00$ for connection. She said he then returned and extorted $\$ 12.00$ from her and her family. Although her identification of him was a bit shaky, as she said she was nearly blind, Ford was convicted of theft of the $\$ 12.00$, and while the one hour in gaol he received as a sentence was insignificant, it was likely one hour longer than he ever thought he would spend in gaol as a result of his behaviour towards her. ${ }^{39}$

In 1891, a man named Wa-Chin was charged with theft of a pony. The Informant was a woman named Swaspekoke who deposed:

I wintered with the Defendant and when he left me he took the pony away with him. Five days after he went away I sent my little boy after the pony. When the little boy came home he told me that the Defendant would [not?] let anybody have the horse. Two days after the boy came home I saw Lemac and he brought me downtown and laid the information next morning. The horse now here in the possession of the police is my property. ${ }^{40}$

Constable Andrews, NWMP, arrested Wa-Chin on Pasqua's Reserve: "When I arrested him he was riding the pony." 41 For his part, Wa-Chin's statement contained on the court file conceded:

\footnotetext{
${ }^{37}$ James B. Mahoney (1878), SAB A-G (GR 11-1) CR-Regina, $1^{\text {st }}$ series, $1876-1886$, file \#54. A woman named Mrs. Mary Hamblyn (who required a Cree interpreter) accused Mahoney of indecently assaulting her when she went to his store for some biscuits. She said he owed her some money. After she pushed him away, he gave her the biscuits. After he received her Information, Richardson sent a letter to Mahoney, indicating that the complaint had been filed, and asking whether he would come to his office. There is no disposition indicated in the file.

${ }^{38}$ William Williams (1882), SAB A-G (GR 11-1) CR-Regina, $1^{\text {st }}$ series, 1876-1886, file \# 172.

${ }^{39}$ James Ford (1889), SAB Coll. RG R1286, file \#11.

${ }^{40}$ Wa-Chin (1891), SAB Coll. RG R-1286, file \#28.

${ }^{41} I d$.
} 
It is true I took the horse away without asking for the use of it, but I intended to return the horse when I was done with it. I asked my little halfbrother for permission to sell the colt, but that was neither here nor there. ${ }^{42}$

The court file ends with a record of Wa-Chin's plea of not guilty, and a note that "Horse restored to prosecutor."

Swaspekoke and O-Cha-nak-kis turned to the law for assistance, and while the criminal justice 'returns' were modest, especially in the paltry sentence of one hour in gaol imposed on James Ford, each woman received restitution. Clearly Cst. Ford thought he could enter an Indian camp and take a woman "for connection." -- a gendered and racist assumption and practice not unique to him. ${ }^{43}$ However, of greater interest to me are the expressions of agency of women in socially subordinate positions, which neither denies their oppression nor their substantive inequality.

\section{ii. An Aboriginal Jury of Matrons and Scholastique Cardinal's Pregnancy (1882)}

In this section I consider, more tentatively, the extent to which the presence of "Aboriginal values" and "inter-communal norms" the court files. To do this, I revisit Jeremy Webber's exploration of "cross cultural community" and his argument that "social orders are marked simultaneously by relations of power and relations of justice...," ${ }^{, 45}$ which often permit "alliances across the cultural divide." ${ }^{, 6}$ For the purpose of this paper, I want to suggest that Webber's analysis can be applied to the "unequal intercommunal relations" in the North-West Territories. The norms invoked or applied in Richardson's court were not simply those imposed by the dominant social order. But old norms and values also appear to have found expression and support in the criminal court.

In 1882, Scholastique Cardinal, an eighteen year old woman of the western community of Lac La Biche (north of Edmonton), was charged with

\footnotetext{
${ }^{42} I d$.

${ }^{43}$ See Carter, Capturing Women: The Manipulation of Cultural Imagery in Canada's Prairie WEST 160 (1997).

${ }^{44}$ Webber, supra note 18.

${ }^{45}$ Webber, supra note 18 , at 629.

${ }^{46}$ Webber, supra note 18, at 630.
} 
murder and concealment of birth of her newborn infant, ${ }^{47}$ following "an investigation" by the women in her community. The women deposed that they had noticed that she had a big belly over the winter, but no longer. And, there was no baby. When she was silent in response to their questions, one of the women grabbed her breasts and expressed milk, and only after this, did she take them to the side of the lake where the baby was found buried. The women took her head scarf and wrapped the baby's body in it, and laid the baby on the table in her house. The file contains the depositions of the people of Lac La Biche, and not a single police officer. She was committed for trial, and pleaded guilty before Richardson. Her sentence was deferred. The entire process appears to have been driven by the women of Scholastique Cardinal's community. There is no mention of who the father might have been, and of course one wonders whether the husband of one of the 'jury of matrons' might have been implicated. In any event, the method of determining whether Scholastique had recently given birth to a baby was not one (arguably) that would likely have been deployed by the NWMP, had they ever become involved in the matter in the first place.

\section{iii. Aboriginal Witnesses: Linguistic and Cultural Interpreters and Interpretation}

That many Aboriginal people appear as witnesses in the Richardson records is not particularly surprising; ${ }^{48}$ however, given the legal and cultural issues involved, the paucity of legal scholarship in the area of linguistic interpretation, including issues of cross-cultural interpretation, is more surprising. ${ }^{49}$ The receipt of their evidence posed two major challenges, one which might be characterized as linguistic, and another which went to the issue of their competency as witnesses. In this part, I consider the issues raised by aboriginal witnesses, their interpreters, and the interpretation of Aboriginal culture in court.

\footnotetext{
${ }^{47}$ SAB A-G (GR 11-1) CR-Regina, $1^{\text {st }}$ series, 1876 - 1886, file \#145.

${ }^{48}$ See Loo (1996), supra note 23, at 77; Wright, The Problem of Aboriginal Evidence in Early Colonial New South Wales in Law, History, Colonialism: The Reach of Empire 140 (Kirkby and Coleborne eds., 2001).

${ }^{49}$ Notable exceptions include Eades, Lawyer-Client Communication: "I don't think the lawyers were communicating with me" Misunderstanding Cultural Differences in Communicative Styles, (2003) 52 Emory L. J. 1109. The Manitoba Aboriginal Justice Inquiry recognized the importance of the issue, and commissioned Freda Ahenakew and her colleagues to produce a research paper for their Inquiry: Ahenakew, Freda, King and Littlejohn, Indigenous Languages in the Delivery of Justice in Manitoba: A Paper Presented to the Public Inquiry into the Administration of Justice and Aboriginal Peoples in ManitoBa Aboriginal Justice Inquiry Research Papers (1991).
} 
An often-repeated story in the social historical literature of the 1885 North-West Rebellion trials tells of Chief One Arrow's response when the felony treason indictment against him was read to him. Having heard the indictment which, when interpreted into his own language, accused him of knocking the Queen's bonnet off her head and stabbing her in the behind, One Arrow is said to have asked the interpreter if he was drunk..$^{50}$ One Arrow was offended, as he had never met the Queen, much less knocked off her bonnet.

Chief Big Bear, who was also tried in 1885 on the same charge as One Arrow and Poundmaker, among others, had long been misunderstood. In 1876, he arrived at the Treaty Six negotiations at Fort Pitt, after Sweet Grass and the others at Fort Pitt had agreed to take the Treaty, and after the most experienced interpreter, Peter Erasmus, had left. Erasmus had emerged through the Treaty Six meetings as the most competent, respected and trusted interpreter; his assessment, for instance, of Peter Ballendine (who had been retained by the Treaty Commissioners to act as one of their interpreters) was that Ballendine had neither the command of the Cree language nor the rhetorical skills to interpret and convey the complex legal concepts that were involved in the Treaties. ${ }^{51}$ Big Bear's words to Alexander Morris may have been interpreted by Ballendine, and it is now generally accepted that his meaning was not conveyed properly. At one point, he said to the Commissioner that he feared the white man's rope being placed around his neck; this was conveyed to and understood by Morris to mean that Big Bear literally feared the death penalty, rather than metaphorically the yoke of indenture and the loss of freedom. ${ }^{52}$ While the idioms and metaphors of the Cree language, and customary practices and courtesies, were likely lost on Morris, Big Bear's analogy of the treaties as bait for a trap was likely well enough conveyed and understood by both of them.

A challenge of considerable proportion is the issue of transcription of the interpreted statements or depositions in the court files. When an Aboriginal deponent spoke in Cree or Saulteaux, for instance, we have no record of what was actually said. The records contain transcriptions that surely involve both cultural and linguistic forms of interpretation. Every level was surely fraught with uncertainty: many of the concepts and phrases relevant to an Anglo-

\footnotetext{
${ }^{50}$ Stonechild and Waiser, supra note 30, at 200; BeAl and Macleod, supra note 30.

${ }^{51}$ Erasmus, Buffalo Days and Nights As Told to Henry Thompson. Introduction by Irene Spry 241 (1976); see also Christensen, Ahtahkakoop: The Epic Account of a Plains Cree Head Chief, His People, and Their Struggle for Survival 1816-1896 237 (2000).

${ }^{52}$ See, e.g., Dempsey, supra note 8; MillLer, supra note 8, at 80-83.
} 
Canadian criminal legal process had no correlation in the indigenous languages; the frailty of the interpretation (especially when the first language of the interpreters was not the Aboriginal language); the standing of the interpreter, the transcription of the interpretation by a court official. And, in addition to the questions of the text, contextual questions of how the Aboriginal deponent or complainant came to be in court and the personal and inter- and intra-community relations that may have been important and relevant must not be forgotten.

Interestingly, there were few challenges to the competency of "non Christian Indians" to testify. Richardson seems routinely to have followed the procedure set out in the Indian Act, ${ }^{53}$ and then proceeded to receive their evidence. For instance, in the trial of the Snake Indian in November 1882, three Cree witnesses, including a young child, gave evidence through interpreter Louis Laronde at the trial before Richardson. ${ }^{54}$ The child witness, K, was described as "non English non Christian Cree Indian girl;" her mother was also described as "non English speaking Cree Indian who appears destitute of the knowledge of God and of any fixed and clear belief in religion;" the third witness testified that she was the child's grandmother. The evidence of all three witnesses was received after they were "cautioned" pursuant to the Indian Act.

In 1902, Tom Lemac, described in court as "a Christian Indian who formerly went under the name of Wingegee," 55 was tried with the 1894 shooting death of Josiah Matoney, also known as Oskinoway. The evidence was that Lemac had last been seen a few days after Oskinaway's death, and then had been in the United States until his arrest eight years later. There were no witnesses to the shooting and there was no direct evidence that Lemac had shot the deceased man. One witness testified that he had seen Lemac and Matoney leave Fort Qu'Appelle on horseback on the September evening that

${ }^{53}$ The Indian Act, 39 Vict. C. $18, \S \S 74-78$ governed this process. $\S 74$ permitted the receipt of evidence on the affirmation to tell the truth:

....it shall be lawful for any court, judge, stipendiary magistrate, coroner, or justice of the peace to receive the evidence of an Indian or non-treaty Indian, who is destitute of the knowledge of God and of any fixed and clear belief in religion or in a future state of rewards and punishments, without administering the usual form of oath to any such Indian, or non-treaty Indian, as aforesaid, upon his solemn declaration to tell the truth... ${ }^{54}$ Ka-nah-pic-a-nah-haw, or the Snake Indian. (1882), SAB A-G (GR 11-1) CR-Regina, $1^{\text {st }}$
series, 1876-1886, file \# 172 .

${ }^{55}$ Tom Lemac (1902), SAB Coll. RG R1286, file \# 266. 
Matoney (Oskinoway) was shot. The wounded Matoney was found alone near the trail the next morning, and was taken to the nearby home of William and Elizabeth Daniels, where he died. Elizabeth Daniels testified that she had heard two people passing by late at night, talking in Saulteaux in an angry manner:

I could not take up their words but still it is easily known when people speak angrily with each another she speak roughly. I understand Saulteaux. I could not hear what was said but I knew they were angry.

There was also evidence that Lemac returned in the morning looking for Matoney. The theory of the Crown was that Lemac blamed Matoney for the death of his sister, but the evidence in support of that theory was not strong. The Crown's case rested largely on the evidence of Cree/Saulteaux witnesses who spoke to Lemac and who saw him shortly after the man died. The defence counsel objected to the receipt of the evidence of these Crown witnesses. The following exchanges during cross-examination of Crown witness, Mrs. Aka Moose, after she had been ordered sworn as a witness by Judge Richardson.

Q: You say you believe in God. What kind of God?

A: I believe in the God the white people pray to.

Q: What do you know about that God?

A: The reason I say so is that the white man prays to a god and are always prosperous and get on well.

Q: What has that God done for you?

His Lordship: You are going too far. If anybody has done wrong it is myself and you have your redress against me if I have done wrong.

The transcript reveals Richardson's impatience with the defence lawyer's insistence upon challenging each of the 'non-Christian' witnesses, asserting that he had been following the same practice since 1877, and reminding the lawyer, "I may just as well say that I have taken a little trouble in looking this matter up in English law ..."

In addition to the issue of the competency of the Indian witnesses to testify, Lemac's trial revealed important issues of linguistic and cultural interpretation and their arguably inseverable connection. At the heart of the matter was the meaning of the words Lemac had spoken to the witnesses on the night, eight 
years earlier, when Oskinaway was shot. One of the women to whom Lemac had spoken, Aka Moose, testified that about eight years earlier, he had come into her tent where she had been camped beyond Star Blanket's Reserve:

Aka Moose: I heard Tom Lemac say when he came into the tent "I think I have done wrong." In Cree when anybody talks like that we get afraid. We know he has done something very bad.

Q: What else did he say?

A: When he came to the tent the fire was a little low. We were in bed but not asleep. He said "Are you all asleep?" Then he said "I think I have done something very wrong."

Q: When he said "Are you all asleep?" Did not any one answer?

A: Yes I said I was not asleep. He said "I fired two shots at him and I think I have killed him." I then asked him Whom? He named the man and said Oskinaway.

The witness, Kakoom, described as a Cree Indian woman, whose sister, Peewusk, was married to Wingegee (Lemac), testified that she heard him say: "I fired two shots at Oskinaway and I think I may have killed him."

Q: Did he use the word murder?

A: He said "I think I have killed him."

Q: Did he use the word murder?

A: Yes, that was what he said.

Q: What was he then saying?

A: He said "I killed Oskinaway.

Q: What was he saying when he used the word murder?

Interpreter: Kill and murder are the same word in Cree.

Peter Hourie, the court interpreter was then sworn as the last Crown witness to give evidence as to the meaning of the Indian words.

Q: During the evidence of several witnesses the expression "I have done wrong" was used. What is the Indian word for "wrong"? 

A: Ne-mi-ye-too-tin.
Q: The meaning is?

A: That he has done wrong.

Q: What is the Indian word for "Killed"?

A: NeNepaha, that is the Cree, the Saulteaux is Ginesah.

Q: The interpretation of the word "wrong" has the same meaning as in English?
A: Not with the Indians.
Q: What is the meaning of the word with an Indian?

A: He might have stolen or killed and is the first expression he would use in his language to relate what he had done.

His Lordship: What you mean is that when an Indians uses the expression "I have done wrong" he means he has committed a crime.

\section{A: To that effect.}

Q: When the word "killed" follows "I have done wrong" what meaning has the word to an Indian?

A: There is no word for murder. I cannot find a word for it. The two expressions taken together mean I have committed a murder, the two expressions "I have done wrong" and "I have killed my fellow Saulteaux".

When pressed by defence counsel on cross examination, Hourie maintained there "there is no word for murder in the Indian language." ${ }^{56}$ Lemac, a former interpreter, guide and assistant for the police, ${ }^{57}$ was convicted of murder and sentenced to death. His sentence was commuted to life in prison. It appears that he was about sixty-five years of age at the time of his conviction.

\footnotetext{
${ }^{56}$ This continues to be an issue of relevance: see, e.g., Monture-Okanee, Reclaiming Justice: Aboriginal Women and Justice Initiatives in the 1990s, in Royal Commission on Aboriginal Peoples, Aboriginal Peoples and the Justice System, Report of the National Round Table on Aboriginal Justice Issues 105, 121 (1993).

${ }^{57}$ Lemac was likely the man to whom Swaspekoke (whose case I have discussed earlier in this article) complained that Wa Chin had taken her pony, and who took her to the justice of the police.
} 
I wish to make two points here. First, the express consideration in Lemac's trial of the meaning and interpretation of language, of concepts from two different cultures, offers supportive evidence for my ever present concern that the interpreted and transcribed words of the Aboriginal deponents may or may not represent their original meaning. Without the original words in their original language, we are left with imperfect sources and, inevitably, imperfect understandings.

The second point to be made concerns the issue of the interpretation of culture, and by whom. ${ }^{58}$ In Lemac's case, the Indian witnesses time and again attempted to explain the significance of a symbol, a gesture, a measure of time, to the judge and jury. This is what Mrs. Aka Moose seems to have been doing when she said, "When an Indian says this ..." While it is a distinct and unsettling possibility that Peter Hourie was editorializing in his interpretation, it nonetheless appears that the Aboriginal witnesses were attempting to make their culture understood. For instance, in responding to a question that implied that a conversation must have taken a long time, a witness answered, conveying the courtesy expected to be shown when listening to another:.

Q: How long was he with you?

A: It would be about an hour. When Indians meet like that we listen till he is through and then we separate.

Or, when asked in cross-examination about the effect of liquor upon Indians, Bazil Mozine offered an explanation as well as a gentle reminder that liquor also affected the behaviour of white men:

As far as I know about this liquor business let a man be ever so quiet and if he gets full of drink it makes him foolish and he loses all memory of what he does. It has a little of that effect upon white people. I have known certain white person and when he got drunk he wanted to fight me but when he was sober he was very quiet.

A later case from the south illustrates a somewhat different set of converging values and gendered, inter-communal relations. In mid-November, 1901, a Sioux woman informed a staff sergeant of the North West Mounted Police at Wood Mountain that her husband, Ce Tan, had left his tepe and gone off with another woman. Ce Tan was charged with deserting his family. His

\footnotetext{
${ }^{58}$ See also, Loo, Savage Mercy: Native Culture and the Modification of Capital Punishment in Nineteenth-Century British Columbia, in Qualities of Mercy: Justice, Punishment AND Discretion 104-129 (Strange ed., 1996).
} 
wife's deposition appears not to have been taken down by the justice of the peace, so we do not know her name or even her own words through an interpreter. But Staff Sgt. Watson deposed that the man's wife had

...stated that she had no food for herself and two children and being left alone with these two children she was unable to support them. First she was afraid to leave them alone in the tent while she went out to work, and secondly she was in an advanced state of pregnancy, about seven months gone, and unable to do any hard work.

Staff Sgt. Watson further deposed that he himself had observed her inability to do heavy work: "I know this latter statement to be a fact as coming here to work she was unable to finish the work and had to go home and leave it." Staff Sgt. Watson was unable to locate Ce Tan as many stories were reported as to his whereabouts. On November 29, on his way to the Willow Bunch, Staff Sergeant Watson was stopped on the trail by a Mrs. Bokas: "she stated she wanted her daughter recovered who had run off with Ce Tan. She also informed me that she had reason to believe that Ce Tan was living with her daughter as man and wife at the Willow Bunch." When he arrived at the Willow Bunch, Staff Sgt. Watson told a constable to go to the Indian camp and tell Ce Tan to return to his wife and family, which the constable said he did do. Upon his return, the staff sergeant was approached by "Bocas Sr and his wife" and asked again to endeavour to recover their daughter for them.

Further evidence before the justice of the peace was provided by Fred Brown of Wood Mountain who indicated that after Ce Tan went away, his family came to Brown's place and Brown gave them something to eat. Brown stated that he had known Ce Tan for twenty years, but could not say that "he is married to the Indian woman"-"only that he lives with her." Another deponent was a man named W.H. Ogle:

Well about the time that Ce Tan went away Mr. and Mrs. Bokas came to me and told me that they wanted to get their daughter back and what was the best way to go about it. I told them to come up to the police post and apply to Dr. Watson through the Gov't interpreter which they refused to do and several days afterwards kept bothering me with the same complaint. They informed me that they considered that they had some claim to my services, it being chiefly through my representations that they sent some of their grandchildren to school, and they considered 
that being one of the few Indians who had obeyed the wishes of the Govt. in that respect that the Law ought to protect them in the case of their daughter. I went with them and reported to Dr. Watson that they wanted their daughter taken away from Ce Tan.

Ce Tan ultimately returned home under what is described in the court file as "police escort" to face an information that:

...from Nov 13th 1901 until Dec 8th Chaton Sioux Indian in company with Lilla Bokas did visit Willow Bunch \& during that time did leave his wife and two children without providing the necessaries of life for them and his wife being in an advanced state of pregnancy he did thereby endanger her health.

When given the opportunity to make a statement at the hearing before the justice of the peace, Chaton, or Ce Tan is said to have stated: "I am sorry for what I have done and did not understand that I was doing any wrong." He was committed to stand trial at the next sittings and he was released from custody pending trial on a recognizance signed by W.H. Ogle.

This case may appear to be simply another unreported case, of limited legal significance, and certainly of no precedential value. Indeed, it is not even clear whatever happened, legally or otherwise, to Ce Tan, for although he was committed to stand trial at the next sittings of the NWTSC in Regina, the Court documents contain no endorsement of the Supreme Court justice. There is no record that he ever appeared at court in Regina. The statistical information contained in the crime reports of the Annual Report of the N.W.M.P for 1901 and 1902 reveals that one case (same offence as Ce Tan) was dismissed. ${ }^{59}$

Ce Tan's case suggests another instance of inter-communal relations, if not norms. We see different forms of demands, expressions of entitlement and formal as well as informal levels of participation in the criminal process. Ce Tan's wife appears to have been employed as a housekeeper by the police. The police were aware that she and her children had been left by her husband. Although the formal charge laid against her husband related to his failure to provide her with the necessaries of life, it also appears that the parents of the woman with whom he had gone off were also an animating presence in the criminal process. They may not have had a legal claim to the intervention of the police but they appear to have articulated a moral claim, expressing the

\footnotetext{
${ }^{59}$ The entry in Criminal Docket Book for the Supreme Court of the North-West Territories indicates only the date that the documents were received at the Court.
} 
view that as far as they were concerned, the white community owed them something for their loyalty.

\section{Conclusion}

The use of Canadian criminal law to sanction and punish the Aboriginal Peoples of the Plains, to constrain their traditional practices and way of life, is revealed in a number of the cases in the Richardson court records, as is their defiance and resistance as well as their own use of it to seek redress. Whether one characterizes some of this activity as resistance to government policies and practices or as criminalization of aspects of everyday life, or both, one thing is clear from the Richardson records: Aboriginal accused found themselves in a criminal court that emerged almost from nowhere in 1876. The numbers of Aboriginal accused persons actually prosecuted were not enormous, but they were significant.

However, the focus of this article has been on another aspect of the engagement and relationship between Aboriginal people and Canadian criminal law in the last quarter of the nineteenth century. From my research into the NWT court records, I suggest that it is at best premature to speak of the criminal law and criminal court as the site of inter-communal norms. But I am interested in inter-communal relations and I argue that social relations of inequality, including legal relations, are still relations. What can one conclude from the presence and form of Aboriginal voices in the Richardson court files? I suggest two fragmentary images.

The first is an image of flexibility, resourcefulness and expectations of good faith on the part of the First Nations peoples who turned to law or who found themselves unwillingly there. For some, Richardson's court was one possible avenue of redress for injuries and wrongs. Their good faith was not always rewarded, but many seem to have obtained the results they were seeking. They were experiencing relations of inequality, to be sure, but in this paper, I have attempted to illustrate the 'inter-communal' and 'relational' nature of this inequality. I argue that its contradictory expressions merit, indeed require, identification, analysis and understanding.

The case of the Pondmaker's disputed horse race, perhaps more than any other, illustrates the 'inter-communal' nature of social relations in the small community of Battleford in 1878. The most interesting aspect of the case is that is not that a criminal prosecution was commenced; rather, the social relations that it revealed. Indians, policemen and cooks had placed bets on the 
race. The judges chosen were a prominent Métis man and Cree interpreter and a North-West Mounted Police Captain. When the race was run, and the Pondmaker's horse lost, several members of the Battleford community appear to have stepped in to lend him support, including the stipendiary magistrate. The Court file does not suggest great support for Ballendine's position, whilst providing some evidence of community support for the Pondmaker. While the court file suggests that the matter was never resolved in court, many from diverse communities - the Cree, Métis, NWMP and other leading lights of Battleford - all men to be sure, were clearly animated by the race and its aftermath, not least perhaps because the 'gentlemen's agreement' had not been kept and a fair race had not been run.

The second image is more tentatively offered than the first: it may be that in this early period, the First Nations felt they had a right by virtue of the Treaties they had entered into with the Canadian state to call upon the police and the court for assistance and redress. This is one inference that certainly can be drawn from the presence of Chiefs and Head Men (Councillors) as Informants in the court files. And, it is one which E. P. Thompson identified in "Consequences and Conclusions" at the close of Whigs and Hunters: that of the mediating role of (criminal) law in social relations - a legal form which occasionally inhibited the powerful in the interest of and at the behest of the less powerful. This is not the dominant image one generally has of the relationship of First Nations people and the Canadian criminal law, but it may be, paradoxically, that the criminal law, unlike that of the Indian Act, was one area of law in which the wardship of Indian people yielded, and a measure of equality in vastly unequal circumstances was permitted. 